DOI: $10.1515 /$ hssr -2015-0027

HSS IV.3 (2015)

\title{
Vintilă Horia and Trans-Temporal Travel
}

Pompiliu Crăciunescu*

West University of Timişoara

\begin{abstract}
The Romanian-born European writer Vintilă Horia - whose birth centenary is celebrated this year - was a genuine searcher of truth. His entire work pleads for transgressive-integrating knowledge, in opposition to binary logic and scientism; it is the privileged space of articulation between cognition, creation and gnosis, between the apophatism of science, mystic apofatism and artistic apofatism. Although much less known than the trilogy of exile - Dieu est né en exil (1960), Le chevalier de la résignation (1961) and iPerseguid a Boecio! (1983) the small-sized novel Le voyage à San Marcos (1972) acts as an exemplary attestation to this pompous conjunction. The current article focuses especially on the text's trans-temporal valence.
\end{abstract}

Keywords

Travel, Transgressive knowledge, Memory, Time, Trans-temporality, San Marcos, Hidden Third Party.

\section{Introduction}

The work of Vintilă Horia (1915-1992) - winner of the Prix Goncourt in 1960 for the novel Dieu est né en exil (God was born in Exile) - highlights, at all its levels, the writer's transgressive vision of the World; a vision in which literature, philosophy, science and theology work together for one and the same goal: the undivided knowledge of the complex Reality within whose horizon man lives. If the "infinite abundance" of Reality (Werner Heisenberg) supposes very diverse techniques of investigation, its undivided knowledge calls for the transgression-inclusion of all these paths. Obviously, in

\footnotetext{
* Faculty of Letters, History and Theology, West University of Timisoara, Bd. Vasile Pârvan 4, 300223, Timisoara, Romania; pompiliu.craciunescu@e-uvt.ro
} 
this approach, the ontological component plays a crucial role: by overcoming the Object-Subject cleavage, the new knowledge means a high connection between science and conscience.

During the last century, Vintilă Horia was one of the few writers of Reality, together with Ernst Jünger, Raymond Abellio, James Joyce and René Daumal. Both in his theoretical and analytical writings - such as, for instance, Introducción a la literatura del siglo XX (Ensayo de epistemología literaria) [Introduction to the literature of the 20th century (An Essay of Literary Epistemology)] ${ }^{1}$ -, on the pages of his Journal d'un paysan du Danube [Diary of a Danube Peasant] or, especially, in the novels which make up his transliterary $\operatorname{cosmos}^{2}$, Le chevalier de la résignation [The Knight of Resignation] (1961), La septième lettre [The Seventh Letter], (1964), Une femme pour l'Apocalypse [A Woman for the Apocalypse] (1968), Persécutez. Boèce! [Persecute Boethius] (1983), Les clefs du crépuscule [Twilight Keys] (1988) etc. -, Vintilă Horia ceaselessly postulates that man's self-transcendence, his new birth, will not occur as long as the World's open complenitude is not assumed precisely via the transgression-inclusion of all its constitutive levels. Unlike a realist writer, who is subject to the sweet poison of binarity, the writer of Reality projects his vision in the Gödelian opening of the T state - T, from the included third party in Stéphane Lupasco's philosophy ${ }^{3}$-, where rationality and revelation coexist. "Le résultat magique de Gödel - notices the astro-physicist Trinh Xuan Thuan - nous a montré les limites de la raison. Il nous faut donc faire appel à d'autres modes de connaissance, comme l'intuition mystique ou religieuse, informés et éclairés par les découvertes de la science moderne" (1998: 446) ${ }^{4}$. Vintilă Horia's work is the privileged space for the articulation between cognition, creation and gnosis, between the apophatism of science, mystic apophatism and artistic apophatism.

Thus the writer responded, avant la lettre, to "the challenge of the $21 \mathrm{st}$ century" - the unity of knowledge (Morin, 1999). Emerging from/through transgression-inclusion, the metaphysics of physics, concentrated in the masterpiece Persécutez Boèce!, is not at all an empty shell; on the contrary, it is the plenary expression of the open unification between the visible and the invisible, between the inner universe and the external universe. Mundus imaginalis or plenitudinous Reality, this third world proves to be the irreducible ground of the new rationality and the sign of the undivided man, imagined by Vintilă Horia, beyond the fallen times of history and the "utopia of the 
present". All his illustrious characters - Ovid, Boethius, Plato, El Greco or Rilke - are inscribed on the trans-temporal orbit oozing from the mysterious "Reality of the future", a realm on which the undivided man will see the light of day. The man to come is "celui dans lequel ce qui fut rencontre celui qui sera, dans un espace-temps non-euclidien" (Horia, 1966: 252) 5 . Run in, through and beyond the fragmented realms of sciences, arts and philosophy, Vintilă Horia's questa remains, at the same time, deeply anchored in philosophy, art and science, just like the man who will come means the secret encounter at the core of the plenitudinous- Gödelian Reality with the one who he was.

Among the not so few examples that illustrate this pompous simultaneity, I shall focus on a small-sized novelistic text, Le voyage à San Marcos [The Journey to San Marcos], which can be simultaneously circumscribed to the tradition of the inner gaze (along the line of AugustineFichte-Husserl), but which, just like other novels by Vintilă Horia, continues to find its way, surreptitiously, through the "noise of our century"; "Comme des épées silencieuses - wrote the author in 1966, mes livres se faufilent parmi les bruits du siècle" (idem, ibidem: 84) 6 . It falls upon our spirit to notice their furtive-salutary blows.

\section{Le voyage à San Marcos: epistemiology, temporality and transdisciplinarity}

Dedicated to his spiritual brother, Ernst Jünger, the novel Le voyage à San Marcos expresses the conviction that literature is a knowledge technique that is on a par with all the others. What is more, for Vintilă Horia, this technique has a unique transdisciplinary potential: "Esta técnica del conocer con posibilidades epistémologicas, en un sentido más bien estético que cientifico, es la novela. La literatura en general, y la novela en especial podría ser el terreno más propicio para un acercamiento entre las diversas técnicas del conocimiento humano" (1976: 17). ${ }^{7}$

Le voyage à San Marcos comes to life along the orbits of a fractal time, perceived as "l'effort que font les êtres et les choses pour se séparer de l'espace et y revenir" (1988: 112) . As an expression of this effort, the text breaks with the consecrated determinism of narrative, and it positions itself on the orbit of the transgressive temporality which governs the previous novel, A Woman for Apocalypse (1968). The epic mode emerges here from the 
dialogue - with multiple monologue interstices - between the protagonist, an ethnologist who, initially, has no name, and Beatriz, a beautiful Spanish woman. The dialogue unfolds during an afternoon in Madrid $_{2}$ as well as far beyond it. Simultaneously, the protagonist lives "in trois espaces différents: celui de la réalité présente, est-ce la Réalité ?, si déchirante; celui de la mémoire, plus proche du réel, je veux dire de mes assises favorables; et celui de l'imagination, mon unique alliée, où tout se combine en ma faveur, ma vraie complétude et qui me pousse vers un éclaircissement" (1988: 112) $)^{9}$

The most solid of these spaces is the time of memory; it structures the novel and juxtaposes three episodes from the protagonist's past. Each episode is coagulated around the same motive: San Marcos.

First, there was San Marco in Venice, the brutal possession of Laura, vanity mixed with pity, and this (gnostic) revelation: "Le lit est le berceau de l'amour et de la mort, le véhicule immobile" (1988: 31) ${ }^{10}$. The carnal side of love - "L'amour comme acte pur n'existe pas"11, ponders twice the protagonist (1988: 33, 39) - betrays not only the Eros-Thanatos collusion, but also the self-cognitive dimension of desire: “mon désir d'elle n'est qu'un désir de moi, reflété, réfléchi, redoublé par son passage à travers l'âme et le corps de cette femme si belle, ou intéressante, ou simplement excitante, ou bien rimant avec mes angoisses et mes vœux de joie éclaircissante" (1988: 39) ${ }^{12}$. The permanent change of planes from the past to the present and the other way round feeds textual coherence and facilitates the reflexive enclaves thanks to which the three-fold temporal membrane network melts in the simultaneity of the moment.

The second episode, briefly told to Beatriz, but thoroughly projected on the protagonist's inner screen, focalises the twilight of Lacandon people and of the Maya. During a research stay in a village neighbouring Yaxchilán ("green stones"), in Mexico, he had discovered the abandoned hermitage that had once been the San Marcos church. "L'animal dont j'avais aperçu la trace, à peine ébauché sur le mur de la chapelle, était sûrement le lion héraldique de Saint-Marc l'Evangéliste, dernier reste d'une fresque effacée" (1988: 54) ${ }^{13}$. The vision on the collapse of the Maya civilisation overturns Charles Darwin and Teilhard de Chardin's evolutionist theories: due to a lack of vital vigour and of memory - "ils ont tout oublié" (1988: 41)14 the Lacand people have come to the point of becoming monkeys. Vintilă 
Horia puts forth a hypothesis that is closely connected to the religion of the Maya, more precisely the idea of time, on which this religion was rigorously articulated.

According to Maya beliefs, the existence of the world would suppose five periods, its end being foreseen for the $10^{\text {th }}$ century. This fact would have instilled, in collective consciousness, the certainty of the apocalypse and, consequently, the vigorous participation of the population to its own disappearance, by the refusal to procreate: "Leurs femmes ne voulaient plus continuer la vie. Elles avaient été la vie pendant des siècles ou de millénaires, elles avaient fait leur devoir dans un milieu favorable à la continuation, et elles étaient devenues la mort par laquelle les Mayas mettaient fin à leur mission ici-bas et devenaient, sous le nom de Lacandons, des sentiers sans issue, de moins en moins nombreux, recouverts peu à peu par la toute-puissance de la jungle et de leur entropie particulière. Et c'est peut-être ainsi dans tous les crépuscules humains" (1988: 43) ${ }^{15}$. To turn back in time through this reversed progress implicitly means to restore time its aura-like freshness, the sense of the absolute beginning ("un passé qui se remplit d'avenir", 1988: 57)16. The symbol of the Evangelist testifies to this anti-entropic journey ${ }^{17}$.

The history of the Maya clarifies the mirrors of the present, in which the flicker of another twilight does not cease to increase, not because of a previously known, foreseeable apocalypse but, on the contrary, due to the loss of faith: "Les masques, le clown, le souffleur, images-clefs du début du XXe siècle, celui des acteurs rentrés dans l'enceinte sacrée, s'y proposant comme modèles de vie, oubliant le germe de mort qu'ils portent en eux, qui s'empare de la cité par leur présence nocturne, qui la voue à Thanatos. Le prêtre est remplacé par l'acteur. Les prêtres deviennent des acteurs" (1988: 69) ${ }^{18}$. Or, when priests "deviennent des acteurs et ceux-ci règnent sur les consciences, alors, nous glissons lentement dans le piège éternel" (1988: 79) ${ }^{19}$; this is what le progrès à rebours means. For Beatriz, the Spanish civil war is inscribed precisely in this process, as it "s'est jouée autour de l'amour, de deux façons opposées de concevoir l'amour. Ce fut un combat entre l'amour sacré et l'amour profane" (1988: 82) ${ }^{20}$. Beatriz is a catalyst for the protagonist's identity questa; accompanying him on the realms of his own memory, she enhances the cognitive valence of love, beyond "notre fragment périssable" (1988: 99) ${ }^{21}$. 
A third incursion in the space of memory is an episode unfolding in Vienna, at the heart of harsh times of famine and barbarity. There, one night in the autumn of the year 1944, stalked by an unknown person - for a sack of potatoes, he intimates -, the character finds a refuge behind San Marco d'Aviano's statue, put up in a niche on the façade of the Capuchin monastery. This is not the Evangelist but an Italian San Marco "qui portait la croix devant les armées chrétiennes au moment où le roi Sobieski de Pologne vint libérer Vienne assiégée par les Turcs"; yet, "c'était le nom qui comptait, n'est-ce pas ?” (1988: 119) 22 .

\section{Le voyage à San Marcos: ontology and symbolism}

We are therefore under the dominance of signs and of the symbol that the thinker configures at the scale of the entire novel. In fact, this journey is not one to (San Marcos), but a journey under the auspices of Saint Mark; a journey in life, under the sign of a beginning, which is something that the hero only becomes aware of in Beatriz's company, whose name is selfrevealing: "Je rêve, ou je suis mort depuis longtemps et cette femme, cette « Mère » comme Goethe l'aurait appelée, est en train de me révéler la réalité dans laquelle je viens d'entrer, dans laquelle je me trouve depuis longtemps sans m'en douter. Il y a renversement. Beatriz est un agent secret de l'éternité" (1988: 101) 23.

To reveal Reality means to reveal the sacred dimension of Reality, the one which remains unseen but to which we belong. Beatriz-Beatrice's reflection is grounded in it: 'Je sépare la vie en deux phases bien nettes : ce qu'on voit et ce qu'on vit ici-bas, qui n'est pas à crier d'enthousiasme, mais qui laisse une porte entrouverte vers ce qu'on ne voit pas, mais qui nous appartient pour toujours" (1988: 74)24. Beatriz is the one who seizes the meaning of the protagonist's "encounters" with Saint Mark, almost never recognised, but whose presence "annonçait toujours quelque chose" (1988: $24)^{25}$. In fact, the very epico-sophical construction is set off by the same symbol, San Marcos, which is also the name of a hotel-hospital in Leon, along the old pilgrimage path to Santiago de Compostela.

"Tout ce qui est de l'ordre de l'esprit, writes Werner Heisenberg, que ce soit dans le langage, dans la science ou dans l'art, repose sur l'intervention et sur la force des symboles" (1998: 347) ${ }^{26}$. Without designating "something determined", for "dans sa forme originaire [il] se tient tout près 
de la région centrale des facultés créatrices", the symbol "nous dispose à l'accueil et il ouvre les portes qui mènent à des régions de réalité difficilement accessibles" (idem, ibidem: 348$).{ }^{27}$ The symbol has to do with the Reality of meaning, which traverses All levels of Reality. Associated to the spirit, it belongs to certain "connexions qui ne peuvent être ni ordonnées dans l'espace et le temps, ni reliées de manière simple à l'espace et au temps" (idem, ibidem: 354) ${ }^{28}$. Thus conceived, the symbol transgresses the consecrated meaning: it becomes an operator of generalized reliance ${ }^{29}$.

Vintilă Horia's Saint Mark is not only the Gospel and the beginning but also "San Marcos dans l'avenir, peut-être, essuyant la trace de tous les autres" (1988: 16) ${ }^{30}$. He, too, is also the connector between "the three different spaces" (and multiple times) in which the two characters meet: the one of Reality, the one of memory and the one of imagination or completitude. San Marcos is the symbol of man himself, to the extent that "nous répétons [...] l'histoire de la Passion, c'est-à-dire un chemin vers la croix, vers ce que nous sommes réellement" (1988: 124) ${ }^{31}$. To meet San Marcos means to find bimself again and thus seize the Reality of the meaning of Reality: "Ce qui compte c'est le regard que je fixe sans entrave dans les yeux invisibles de mon saint, qui finit par prononcer mon nom: Marc, dit-il, et c'est comme un tonnerre de silence qui fait frémir l'église de ma vie. Et tout ce que je viens de raconter à Beatriz pendant cet après-midi dans le bois devient très clair et je me sens de force à le jeter par-dessus bord, dans ce taillis, afin de pouvoir garder ce contact et de ne plus m'en détacher. Je suis arrivé au bout de mon voyage, car toute vie en est un et il faut en comprendre le sens, tirer les conclusions et pouvoir ainsi entreprendre le retour, comme les pèlerins d'antan qui, une fois guéris dans cet hôpital, reprenaient le chemin de Santiago et, après, rentraient chez eux" (1988: 125 , s. m. $)^{32}$.

\section{Conclusion}

An original experience and a catalyst for the knowledge of Reality, love, under whose sign the search for the self unfolds, is, at the same time, the experience of time: The Journey to San Marcos cancels out not only the distinction between res cogitans and res extensa, what Husserl called "absurdité cachée" (1976: 86)33, but also the famous temporal arrow. Beyond the fogs of the past and the miasmas of a present soaked in the 
profane - as the novel's epigraph, an excerpt from Romanian folklore, suggests "Et nous, êtres baptisés,/ Par le Verbe abandonnés" 34 -, the transgression-inclusion takes on, here, all its richness of meanings. Thus, the sun of love-knowledge throws a bridge of light between the rational realm and the mystic realm that are combined in human existence and, at the same time, combine the Reality which incorporates being. A journey in the space of memory, Marcos' journey is the perpetual journey of Being in temporal plenitude; for Vintilă Horia, "Tout n'est que mémoire, même le Jugement dernier, notre dernier acte de l'histoire.” (1966: 22)35.

Along an isomorph orbit gravitates Ernst Jünger's mysterious Besuch auf Godenholm/ A Visit to Godenholm (1952), to which Vintilă Horia consecrates a brief paragraph in Introducción a la literatura del siglo XX: "Los personajes no son más que la memoria de lo que fueron y Godenholm puede ser traducido como el hogar o la isla (en alemán antiguo) de los Dioses, es decir los Campos Eliseos" (1976: 378) ${ }^{36}$.

Under the dominance of goddess Berchta and guided by the wise Schwarzenberg/ Caron, Moltner, Ejnar and Ulma are initiated into Truth through death ${ }^{37}$; under the dominance of Beatriz, Vintilă Horia's protagonist becomes aware of the infinite hope which makes possible the history of people and, at the same time, the eternity that they crave. If "Beatriz est un agent secret de l'éternité"38, Vintilă Horia, just like Dante, Novalis or Jünger, is a secret agent of the Third Party. Or, as Basarab Nicolescu writes, "a Source of Reality, the Hidden Third Party feeds on this Reality, in a cosmic breath that includes us and the universe" (2009: 234) ${ }^{39}$. This is the irreducible role assumed by Vintilă Horia in his Grand cognitive Game. The awake consciousness of his century, just like Jünger, Heisenberg, Joyce, Lupasco or Husserl, Vintilă Horia sends us through his work to our own mission, i.e. to transcend ourselves. This is why he is a writer for the third millennium.

\section{References}

Jünger, E. (1999), Vizită la Godenholm.Vânătoare de mistrețt [Visit to Godenholm. Hunting for Wild Bears]. Translation by Sorin T,igăreanu and Ingrid-Irene Macarie. Bucharest: Rosmarin.

Heisenberg, W. (1998). Philosophie. Le manuscrit de 1942 [Philosophy. The 1942 Manuscript]. Translation by Catherine Chevalley. Paris: Seuil. 
Horia, V. (1966). Journal d'un paysan du Danube [Diary of a Danube Peasant]. Paris: Editions de la Table Ronde.

Horia, V. (1971). Viaje a los centros de la tierra. Encuesta sobre el estado actual del pansamiento, las artes y las ciencias [Journey to the Centre of the Earth. A Survey of the Current State of Thought, Arts and Sciences]. Barcelona: Plaza \& Janés S. A., Editores.

Horia, V. (1976). Introducción a la literatura del siglo XX. (Ensayo de epistemología literaria) [ntroduction to the $20^{\text {th }}$ Century Literature. (An Essay of Literary Epistemology)]. Madrid: Editorial Gredos.

Horia, V. (1988). Le voyage à San Marcos [The Journey to San Marcos], Paris: Editions du Rocher.

Husserl, E. (1976). La crise des sciences européennes et la Phénoménologie transcendantale [The Crisis of European Sciences and Transcendental Phenomenology]. Translation by Gérard Granel. Paris: Editions Gallimard.

Lupasco, S. (1987). Le principe d'antagonisme et la logique de l'énergie. Prolégomènes à une science de la contradiction [Principle of Antagonism and the Logic of Energy. Prolegomena to a Science of Contradiction]. Foreword by Basarab Nicolescu. Monaco: Rocher.

Morin, E. (1999). Relier les connaissances. Le défi du XXI siècle [Connecting Knowledge. The Challenge of the $21^{1 t}$ Century]. Paris: Editions du Seuil.

Nicolescu, B. (2009). Ce este Realitatea? Reflecții in jurul operei lui Stéphane Lupasco [What is Reality? Reflections around Stéphane Lupasco's Work]. Translation by Simona Modreanu. Iaşi: Junimea.

Nicolescu, B. (2011). De la Isarlîk la Valea Uimirii. Vol. II. Drumul fără sfârşit [From Isarlike to the Valley of Bewilderment. Vol. II. The Endless Journey]. Foreword by Irina Dincă. Bucharest: Curtea Veche Publishing.

Thuan, T. X. (1998). Le chaos et l'harmonie. La fabrication du Réel [Chaos and Harmony. The Fabrication of the Real], Paris: Librairie Arthème Fayard.

*** (1992). Vintila Horia in memoriam. Editión en Homenaje al Profesor Vintila Horia [Vintila Horia in memoriam. An Edition Tribute to Professor Vintila Horia]. Facultad de Ciencias de la Información, Universidad Complutense.

\footnotetext{
${ }^{1}$ The ideatic axes of this fundamental study can already be se seen in Presencia del mito [The Presence of Myth] (Madrid, Escelier, 1956) and Poesia y libertad [Poetry and Freedom] (Madrid, Ateneo, 1959) and they manifest themselves plenary in the dialogues from Viaje a los centros de la tierra. Enquesta sobre el estado actual del pensamiento, las artes y las ciencias. Barcelona: Plaza \& Janés, S.A., Editores, 1971).
} 
${ }^{2}$ As I have shown in a more ample article - Vintila Horia. Translittérature et réalité [Vintilă Horia. Transliterature and Reality], Editions L'Homme Indivis, 2008; Romanian edition: Vintilă Horia. Transliteratură și Realitate. Translation from the French by Olimpia Coroamă. Foreword to the Romanian edition by Basarab Nicolescu, Bucharest: Curtea Veche Publishing, 2011, "Science, spirituality, society" Collection. Acting as fields in which various cognitive paths criss-cross, to the detriment of traditional narrativity, Horia's novels have a pronounced transliterary character.

${ }^{3}$ T State (Included Third Party) proves the existence of an antagonist dynamics which conciliates, at a third level of Reality, heterogeneity (living matter) and homogeneity (macro-physical matter) (Lupasco, 1987). A thorough investigation into Lupasco's thinking, in Nicolescu: 2009.

4 "Gödel's magic result [...] has showed us the limits of reason. Therefore we must resort to other modes of knowledge, such as the mystic or religious intuition, informed and enlightened by the discoveries of modern science" (translator's note).

5 "he in whom what was meets who he will be, in a non-Euclidian space-time" (translator's note).

6 "Just like silent ears of wheat [...], my books sneak through the noises of the century" (translator's note).

${ }^{7}$ The novel is this technique of knowing with epistemological possibilities, in a sense that is more aesthetic than scientific. Literature in general, and particularly the novel, could be the most fertile ground for a rapprochement between the various techniques of human knowledge" (translator's note).

8 "The effort made by beings and things to separate themselves from space and to come back to it" (translator's note). Although written in French, the novel was first published in its Spanish translation (El viaje a San Marcos, Introducción y traducción por Marcelo Arroita-Jáuregui Madrid, Editorial Magisterio español, 1972); I will solely reference the French edition (1988).

9 "three different spaces: the one of the present reality, is it Reality?, so heartbreaking; the one of memory, closer to the real, I mean to my favourable fundamentals; and the one of imagination, my sole ally, where everything combines to my favour, my true completeness and which pushes me towards enlightenment" (translator's note).

10 "The bed is the cradle of love and death, the immobile vehicle" (translator's note).

11 "Love as a pure act does not exist" (translator's note).

12 "my desire for her is nothing but a desire for myself, reflected, pondered upon, doubled by its passage through the soul and body of this woman so 
beautiful, or interesting, or simply exciting, or rather rhyming with my anguishes and my wishes for an enlightening joy" (translator's note).

13 "The animal whose trace I had noticed, barely sketched on the chapel's wall, was surely Saint Mark the Evangelist's heraldic lion, the last remains of a faded fresco" (translator's note).

14 "they have forgotten everything" (translator's note).

15 "Their women did not want to continue life any longer. They had been life for centuries or millennia, they had done their duty in an environment favourable to continuation, they had become the death through which the Maya were putting an end to their mission here, below, and became, under the name of the Lacand people, paths leading nowhere, fewer and fewer, gradually recovered by the all-mightiness of the jungle and of their particular entropy. And this is how it probably is in all human twilight times" (translator's note).

16 "a past which is filling itself up with the future"(translator's note).

${ }^{17}$ A novelist, therefore, not a realist, in the term's consecrated understanding, but in that of Reality (as the complex articulation of its various levels), Vintilă Horia touches, through the symbol-title, the synoptic problem in theology, which concerns relations between the three Gospels. Obviously, the novelist privileges the genealogic model (conceived in 1934 by Austin Marsden Farrer), according to which Mark is the oldest evangelist. In fact, Saint Mark is precisely the symbol of a new historical cycle, a central problem in the prosewriter's work.

18 "the masks, the clown, the prompter, key-images at the turn of the 20th century, the one of the actors who had entered the sacred premises, proposing themselves as model for life, forgetting the germ of death that they carry inside, which gets hold of the city through their nocturne presence, which dedicates it to Thanatos. The priest is replaced by the actor. Priests become actors" (translator's note).

19 "become actors and the latter reign over consciences, then we are slowly sliding down in the eternal trap" (translator's note).

20 "was played around love, around two opposed ways of conceiving love. It was a fight between sacred love and profane love"(translator's note).

21 "our perishable fragment" (translator's note). Beatriz is not far from Beatrice; in fact, Vintilă Horia makes constant (textual or indirect) references to Dante's doctrine, in both his literary and hermeneutic creation. For instance, in Introducción a la literatura del siglo XX, he considers that the author of Divina Comedia synthesised all views on love, from the poets of Provence to medieval theology, astronomy, medicine and philosophy, that is before the age of the gradual disintegration of the sacred. Beatrice is "la fe que revela el conocimiento [...], 
HSS, vol. IV, no. 3 (2015): 109-122

al mismo tiempo la fe y la ciencia" / "the faith that reveals knowledge [...], at the same time faith and science" (1976: 130-131); this corresponds rigorously to Vintilă Horia's cognitive vision, a genuine convergence between science, love and the sacred.

22 "who was wearing the cross in front of Christian armies when king Sobieski of Poland had just liberated Vienna, under attack by the Turks"; [...] it was the name that mattered, wasn't it?" (translator's note).

23 "I am dreaming, or I have been dead for a long time and this woman, this "Mother" as Goethe would have called her, is revealing to me the reality in which I have just entered, in which I have been finding myself for a long time without being aware of it. There is a reversal here. Beatriz is a secret agent of eternity"(translator's note).

24 "I divide life in two well distinguished phases: what we see and what we live down here, which doesn't make one shout with enthusiasm, but which leaves a door ajar towards what we don't see but which belongs to us, for eternity" (translator's note).

25 "always announced something" (translator's note).

26 "All that pertains to the order of the spirit [...], be it in the language, science or art, rests on the intervention and the force of symbols" (translator's note).

${ }^{27}$ In its original form [it] stays very close to the central region of creative faculties" [...] "disposes us to reception and opens the gates that lead to regions of reality that are hardly accessible (translator's note). Heisenberg distinguishes three large areas of Reality, depending on the incidence of the process to know-determine the object: the region of objectifiable things (classical physics), the level of inseparable things (quantic physics, biology and psychology) and the region of things created during the knowledge process (religious experience, inspiration, God's allegory).

28 "connections which can be neither ordered in space and time, nor simply linked to space and time" (translator's note).

${ }^{29}$ Originating in sociology (Roger Clausse, Marcel Boll de Bal), the term reliance gains here a vigorous transdisciplinary semantic charge. Thus, generalised reliance undergirds the transgression-inclusion process, which is fundamental for Vintilă Horia's vision of the world.

30 "San Marcos in the future, maybe, wiping the trace of all others" (translator's note).

31 "we repeat [...] the history of the Passion, that is a path towards the cross, towards what we really are" (translator's note).

32 "What counts is the gaze that I fix, unhindered, in the invisible eyes of my saint, who ends up pronouncing my name: Marc, he say, and it is like a thunder 
HSS, vol. IV, no. 3 (2015): 109-122

of silence that sets trembling the church of my life. And everything that I have told Beatriz this afternoon in the forest becomes very clear and I feel strong enough to throw it overboard, in this thicket, so as to be able to keep this contact and no longer detach myself from it. I have come to the end of my journey for any life is one and one must seize its meaning, draw conclusions and thus be able to start the journey back, like the pilgrims of the past who, once cured in this hospital, embarked again on the way of Santiago and after that, returned to their homes" (translator's note).

33 "hidden absurdity" (translator's note).

34 "And we, baptised folks,/ abandoned by the Word" (translator's note).

35 "Everything is nothing else but memory, even the Last Judgment, our last act of history" (translator's note).

36 "characters are nothing else but the memory of what they have been and Godenholm could be translated as the home or the island (in ancient German) of Gods, that is Champs Elysées" (translator's note).

${ }^{37}$ Although he was not a foreigner to Albert Hofmann's discovery, i.e. LSD, in his text, Ernst Jünger makes no allusion to the drug (unlike Aldous Huxley's essay The Doors of Perception, dating from the same period). In fact, beyond the strict universe of the hallucination-inducing experience, the German writer aims towards a path to knowledge that considers, simultaneously, the rationalism and mysticism of the West. This is also the reason why Vintilă Horia, who had encountered Jünger in Viaje a los centros de la tierra (1971, Con Ernst Jünger en la Selva Negra: 150-159) [Journey to the Centre of the Earth (1971, With Ernst Jünger in the Black Forest], considers the latter as representative for $20^{\text {th }}$ century Western Europe, together with Pasternak, emblematic for another Europe; cf. his last conference (April 1991), Ernst Jünger y Boris Pasternak o las dos Europas [Ernst Jünger and Boris Pasternak or the two Europes], published in *** 1992: 15-32.

38 "Beatriz is a secret agent of eternity" (translator's note).

39 For its theorist, The Hidden Third Party compensates the discontinuity between the various levels of Reality of the Subject and the various levels of Reality of the Object: "This non-resistance area corresponds to a third term, the term of Interaction between the Subject and the Object, which can be reduced neither to the Object, nor to the Subject and which I shall call the "Hidden Third Party" (Nicolescu, 2011: 17).

\section{Biographical note}

Pompiliu Crăciunescu is an Associate Professor at the Faculty of Letters, History and Theology in the West University of Timisoara, an active member of the Centre International de Recherches et Etudes Transdisciplinaires - Paris (CIRET) 
and a member of the Writer's Union from Romania. Between 1997 and 2001 he was Attaché Temporaire d'Enseignement et de Recherche (ATER) in Université "Jean Monnet" of Saint-Etienne. He has published the volumes: Eminescu. Paradisul infernal and Transcosmologia [Eminescu. Infernal Paradis and Transcosmology] (2000), Strategiile fractale [Fractal Strategies] (2003), Vintila HoriaTranslittérature et Réalité (2008; Romanian edition: Vintilă Horia: Transliteratură și Realitate, 2011) [Vintilă Horia: Transliterature and Reality].

(Translated from Romanian to English by Sorina Chiper) 